\title{
Biomass of Fish By-Products as a Component of Compost for Agricultural Use
}

\author{
Maja Radziemska ${ }^{1}, Z_{\text {bigniew Mazur }}^{2}$, Joanna Fronczyk ${ }^{3}$, and Anna Jeznach-Steinhagen ${ }^{4}$
}

\begin{abstract}
The dynamics of changes in pH, temperature, and EC when composting the biomass of fish by-products along with sawdust, straw, bark and lignite were analysed in the experiment. The experiment comprised two series: I- composts at a dose of $1 \mathrm{~g}$ of compost per pot, and II - composts with $0.5 \mathrm{~g}$ of urea. The treatments were conducted on the following types of composts: compost 1: fish waste ( $80 \%$ d.m.), sawdust ( $20 \%$ d.m.); compost 2: fish waste ( $80 \%$ d.m.), straw (20\% d.m.); compost 3: fish waste (80\% d.m.), bark (20\% d.m.); compost 4: fish waste (79.3\% d.m.), sawdust $(19.7 \%$ d.m.), lignite ( $1 \%$ d.m.); compost 5: fish waste $(79.3 \%$ d.m.), straw (19.7\% d.m.); lignite (1\% d.m.); compost 6: fish waste (79.3\% d.m.), bark $(19.7 \%$ d.m), lignite $(1 \%$ d.m). Over the course of the composting processes, $\mathrm{pH}$ values increased up until week four, and reached maximum values in the compost with the addition of straw. All composts were characterized by a systematic increase of EC, with maximum values reached in the last week. The highest values of this parameter were observed in compost with the addition of bark and lignite. The highest crop yield of the tested plant was noted in the case of applying compost containing fish by-products and straw with the addition of lignite, and with bark and lignite.
\end{abstract}

Keywords - Brassica napus L., compost, fish by-product, yield.

\section{INTRODUCTION}

$\mathrm{I}^{\mathrm{s}}$ countries of the European Union, the by-products generated by the fishing industry amount to a total of 5.2 million tonnes year ${ }^{-1}$ [1]. The Regulation of the European Parliament and of the Council on Health Rules concerning animal by-products not intended for human consumption requires products derived from aquatic animals, including fish, to be removed, e.g. by incineration or co-incineration, fermentation, composting or transformation into biogas. Animal waste, which includes the by-products of the fishing industry, may be an excellent component for compost production.

Composting is one of the most effective methods of recycling waste made up of organic matter, with possible uses

Maja Radziemska ${ }^{1}$ Faculty of Civil and Environmental Engineering, Warsaw University of Life Sciences - SGGW, Nowoursynowska 159, 02-776 Warsaw, Poland

Zbigniew Mazur ${ }^{2}$ University of Warmia and Mazury in Olsztyn, Faculty of Environmental Management and Agriculture, Pl. Łódzki 4, 10-718 Olsztyn, Poland

Joanna Fronczyk ${ }^{3}$ Faculty of Civil and Environmental Engineering, Warsaw University of Life Sciences - SGGW, Nowoursynowska 159, 02-776 Warsaw, Poland

Anna Jeznach-Steinhagen ${ }^{4}$ Medical University of Warsaw,

Faculty of Health Sciences, Dietetics Division, 27 Erazma Ciołka St, 01445, Warsaw, Poland in agriculture [2]. The application of organic waste products to soil by first turning them into composts has, above all, economic as well as ecological value, and is regarded as being environmentally friendly. Moreover, it represents a costeffective method of recycling nutrients and carbon in agriculture. Animal by-products of the fishing industry, halfdead fish, or products derived from the processing of fish for consumption purposes can be applied in agriculture and gardening as fertilizer, upon having first been subjected to proper processing; they can be composted and used along with other organic materials [3].

The objective of this work is to prove the value of byproducts of the fishing industry as a good component of compost. The study also aims to determine the dynamics of changes in some parameters of composts produced from fish by-products, containing different variants of additives in accordance to the study method and their influence on crop yield.

\section{II.MATERIAL AND METHODS}

This study was conducted in open air at the Faculty of Environmental Management and Agriculture at the University of Warmia and Mazury in Olsztyn, Poland.

\section{A. Substrates and composting mixtures}

The basic substrate for obtaining compost was the biomass of fish by-products taken from Lake Kortowskie (Olsztyn, Poland): the bleak (Alburnus alburnus), common roach (Rutilus rutilus), common bream (Abramis brama) and white bream (Blicca bjoerkna). The effect of composting depends largely on the quantity and proportions of the components; wheat straw, which is a basic additive applied to composts, was applied as a structural additive. Other substrates included waste products of the foresting industry, i.e. sawdust, due to its ability to absorb moisture and structure ensuring adequate compost porosity, and pine bark. A variant with the addition of lignite was also tested. Lignite caused an increase in the amount of organic substance, i.e. a more favorable C:N ratio. After being ground up, all substrates were placed in layers. The top layer always consisted of organic substances, which were used in order to protect the compost from excessive drying and the effect of atmospheric conditions in the first weeks of the composting process. Table I presents the chemical composition of components used during the composting process. 
TABLE I

CHEMICAL PROPERTIES OF SUBSTANCES USED FOR COMPOSTING (G: KG ${ }^{-1}$ D.M.)

\begin{tabular}{lllll}
\hline \hline \multicolumn{1}{c}{ Parameter } & Sawdust & \multicolumn{1}{c}{ Straw } & \multicolumn{1}{c}{ Bark } & \multicolumn{1}{c}{ Lignite } \\
\hline Organic carbon & $566.2 \pm 7.3$ & $422.6 \pm 9.1$ & $410.0 \pm 8.2$ & $705.0 \pm 12.2$ \\
Total N & $1.92 \pm 0.1$ & $5.53 \pm 0.2$ & $7.04 \pm 0.3$ & $8.40 \pm 0.4$ \\
Phosphorous & $0.40 \pm 0.0$ & $1.12 \pm 0.1$ & $0.62 \pm 0.1$ & $1.16 \pm 0.1$ \\
Potassium & $0.94 \pm 0.1$ & $12.44 \pm 0.6$ & $1.05 \pm 0.1$ & $0.3 \pm 0.0$ \\
Magnesium & $1.12 \pm 0.1$ & $1.16 \pm 0.0$ & $1.32 \pm 0.2$ & $2.9 \pm 0.1$ \\
Calcium & $1.22 \pm 0.1$ & $2.62 \pm 0.3$ & $1.51 \pm 0.2$ & $12.4 \pm 0.5$ \\
\hline \hline
\end{tabular}

The data are indicated by mean \pm standard deviation for triplicate determinations.

\section{B. Monitoring and chemical analyses}

Approximately $200 \mathrm{~g}$ of homogenized compost samples were collected on days $14,28,42,56$ and 70 of the composting process for chemical analyses. Before being subjected to chemical analysis, the samples were air-dried and crushed using a high speed muller, and then sieved through a 1 $\mathrm{mm}$ nylon sieve and stored in polyethylene bottles. The moisture content of the composting mixtures was determined by oven drying at $105^{\circ} \mathrm{C}$ until a constant weight was reached [4]. Total nitrogen and organic carbon were determined using the Kjeldahl and Turin methods, respectively [5]. The $\mathrm{pH}$ and electrical conductivity (EC) of composting mixtures was measured in water extracts using a $\mathrm{pH} /$ conductivity meter (Handylab pH/LF 12 Schott, Germany). Temperature was monitored with a Termometr PT-411 type thermometer (Elmetron, Poland) by taking measurements three times a day from the centre of the compost, in three different locations along the middle of the compost crates, over the entire course of the composting process. Phosphorus and potassium contents were determined using Egner-Riehm's method [6], and magnesium - using atomic absorption spectroscopy (AAS)

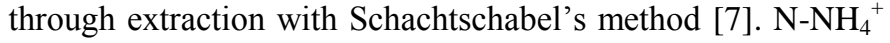
was determined using Nessler's reagent, and $\mathrm{N}^{-\mathrm{NO}_{3}}{ }^{-}$using phenoldisulfonic acid [8].

Before setting up the experiment, the following parameters were determined in the collected soil samples: $\mathrm{pH}_{\mathrm{KCl}}, \mathrm{C}_{\text {org. }}$, $\mathrm{N}_{\text {tot }}$, P, K, Mg, HAC using Kappen's method [9], total exchangeable bases (TEB - $\mathrm{K}^{+}, \mathrm{Na}^{+}, \mathrm{Ca}^{2+}$, and $\mathrm{Mg}^{2+}$ ) using Kappen's method [9], cation exchange capacity (CEC) from the formula: $\mathrm{CEC}=\mathrm{HAC}+\mathrm{TEB}$, and percentage base saturation (V) from the formula: $\mathrm{BS}=100 \mathrm{TEB} / \mathrm{CEC}^{-1}$.

\section{Composting experiment set-up}

Six compost trials $\left(\mathrm{C}_{1}-\mathrm{C}_{6}\right)$ were carried out in specially constructed wooden compost crates measuring $0.5 \times 0.6 \times 0.6$ $\mathrm{m}(\mathrm{WxLxH})$, and made from wooden boards, approx. $10 \mathrm{~cm}$ in width. The experiment was carried out on the following types of mixtures (Table II). Two replications for each type of compost mixture were conducted. The optimal moisture for efficient composting is generally $40-60 \%$ [10]. During the composting process, the humidity of the materials was maintained at a constant level of approx. 60\%, and the compost mass was mixed once a week to aid aeration.
TABLE II

TYPES OF MIXTURES (DRY MASS)

\begin{tabular}{llll}
\hline \hline Compost 1 & fish by-products (80\%) & sawdust (20\%) & - \\
Compost 2 & fish by-products (80\%) & straw (20\%) & - \\
Compost 3 & fish by-products (80\%) & bark (20\%); & - \\
Compost 4 & fish by-products (79.3\%) & sawdust (19.7\%) & lignite (1\%) \\
Compost 5 & fish by-products (79.3\%) & straw (19.7\%) & lignite (1\%) \\
Compost 6 & fish by-products (79.3\%) & bark (19.7\%) & lignite (1\%) \\
\hline \hline
\end{tabular}

TABLE III

CHEMICAL CHARACTERISTICS OF THE APPLIED COMPOSTS $\mathrm{C}_{1}$ - $\mathrm{C}_{6}$ (DRY MASS)

\begin{tabular}{llrlrrrr}
\hline \hline \multicolumn{2}{l}{ Property } & $\mathrm{C}_{1}$ & $\mathrm{C}_{2}$ & $\mathrm{C}_{3}$ & $\mathrm{C}_{4}$ & $\mathrm{C}_{5}$ & $\mathrm{C}_{6}$ \\
\hline $\mathrm{C}_{\text {org. }}$ & $\mathrm{g} \mathrm{kg}^{-1}$ & 425.7 & 418. & 382.8 & 413.4 & 428.7 & 369.9 \\
& & 6 & & & & \\
$\mathrm{~N}_{\text {tot. }}$ & $\mathrm{g} \mathrm{kg}^{-1}$ & 9.21 & 12.1 & 11.4 & 9.93 & 12.5 & 12.2 \\
& & & 3 & & & & \\
$\mathrm{C}: \mathrm{N}$ & & 46.2 & 34.5 & 33.4 & 41.6 & 34.1 & 30.3 \\
$\mathrm{P}$ & $\mathrm{mgkg}{ }^{-1}$ & 2.59 & 2.61 & 2.59 & 2.58 & 2.59 & 2.58 \\
$\mathrm{~K}$ & $\mathrm{mgkg}^{-1}$ & 3.90 & 3.99 & 3.87 & 3.89 & 3.99 & 3.89 \\
$\mathrm{Mg}$ & $\mathrm{mg} \mathrm{kg}^{-1}$ & 1.00 & 1.03 & 1.01 & 1.01 & 1.04 & 1.02 \\
$\mathrm{Na}$ & $\mathrm{mg} \mathrm{kg}^{-1}$ & 0.30 & 0.31 & 0.33 & 0.31 & 0.34 & 0.35 \\
$\mathrm{Ca}$ & $\mathrm{mg} \mathrm{kg}^{-1}$ & 4.90 & 4.97 & 4.92 & 4.92 & 4.99 & 4.95 \\
\hline \hline
\end{tabular}

Composting was carried out over a period of 76 days. The characteristics of the composts have been presented in Table III.

\section{Pot experiment}

The vegetation pot experiment was conducted at a steady temperature of $22^{\circ} \mathrm{C} \pm 2^{\circ} \mathrm{C}$ in a greenhouse. PCV pots filled with $9.5 \mathrm{~kg}$ of soil mixed with composts in accordance to the study procedure were used for this purpose. Soil used in the experiment was characterized by a granulometric composition of $86 \%$ sand $(2.0-0.05 \mathrm{~mm}), 11.2 \%$ silt $(0.05-0.002 \mathrm{~mm})$ and $2.2 \%$ suspended fraction $(<0.002 \mathrm{~mm})$; the soil was collected from the arable layer of a farm field. The soil samples were air-dried and passed through a 5-mm sieve prior to the greenhouse pot experiment. Agrochemical parameters of the soil used have been shown in Table IV.

TABLE VI AGROCHEMICAL PARAMETERS OF THE SOIL

\begin{tabular}{|c|c|c|}
\hline Parameter & Unit & Value \\
\hline $\mathrm{pH}$ & & 5.7 \\
\hline Hydrolytic acidity (HAC) & $\operatorname{mmol}\left({ }^{+}\right) \cdot \mathrm{kg}^{-1}$ & 21.30 \\
\hline Sum of exchangeable bases (TEB) & $\operatorname{mmol}\left({ }^{+}\right) \mathrm{kg}^{-1}$ & 100.00 \\
\hline Cation exchange capacity (CEC) & $\operatorname{mmol}\left({ }^{+}\right) \cdot \mathrm{kg}^{-1}$ & 105.60 \\
\hline Base saturation (BS) & $\%$ & 83.30 \\
\hline Organic carbon & $\mathrm{g} \cdot \mathrm{kg}^{-1}$ & 6.30 \\
\hline Total nitrogen & $\mathrm{g}^{0} \mathrm{~kg}^{-1}$ & 0.54 \\
\hline Ammonia & $\mathrm{mg} \cdot \mathrm{kg}^{-1}$ & 15.40 \\
\hline Nitrate (V) & $\mathrm{mg} \cdot \mathrm{kg}^{-1}$ & 4.02 \\
\hline Phosphorus & $\mathrm{mg} \mathrm{kg}^{-1}$ & 84.76 \\
\hline Potassium & $\mathrm{mg}^{\circ} \mathrm{kg}^{-1}$ & 57.89 \\
\hline Magnesium & $\mathrm{mg}^{-\mathrm{kg}^{-1}}$ & 76.37 \\
\hline
\end{tabular}

When applying organic fertilizers, all essential plant nutrients are introduced into the soil. However, their release into mineral forms is usually slower than in their absorption by the vegetative and physiological development of plants. This refers especially to the forms of nitrogen assimilable by plants. 
As a result of this, the scheme of the experiment accounted for fertilization with either only the analyzed composts or along with mineral fertilization.

The experiment consisted of two series, each conducted in four replications. In the first, the composts were applied in the amount of $1 \mathrm{~g}$ of compost per pot. In the second series, $0.5 \mathrm{~g}$ of mineral $\mathrm{N}$ in the form of urea was additionally applied to the compost. The control pots did not contain compost additives. Additionally, a pot containing fertilizer consisting of animal manure was added to the series. Brassica napus L. was the crop of choice for the experiment because of its high biomass yields and the fact that it represents a commonly cultivated crop in the study area. The experiment was conducted at a density of 10 plants per pot, maintaining the moisture content at $60 \%$ of the maximum water capacity. Rape of the Feliks variety was harvested in the flowering phase, and plant material samples collected for laboratory tests.

\section{E. Statistical analysis}

The results were subjected to statistical calculations using the Statistica 10 software package (StatSoft Inc. 2010), with results of each series subjected to statistical analysis using Tukey's analysis of variance. The series were compared with the t-test for dependent variables, assessing differences between the average results.

\section{RESULTS AND DISCUSSION}

The physiochemical parameters of the analyzed composts were affected by the type as well as composition of materials used for composting. Temperature is one of the most representative parameters of the composting process [11]. changing depending on the rate and degree of organic matter mineralization as well as the intensity of microbiological processes [12]. The changes in temperatures recorded in the compost mass and air have been presented in Fig. 1.

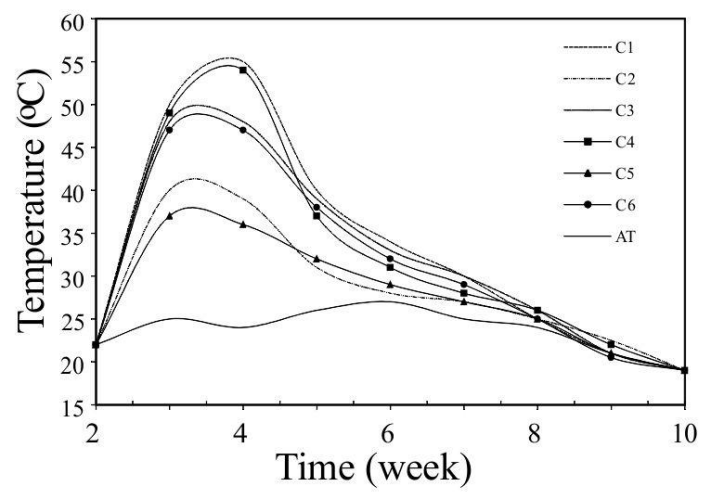

Fig. 1 Changes in temperature during the composting process $\left({ }^{\circ} \mathrm{C}\right)$

The temperature in the bins at the commencement of the experiment averaged $23^{\circ} \mathrm{C}$. During the following days of composting, a significant increase in temperature was observed, reaching maximum values in the first and second week of the process. An initial rise in temperature occurs regardless of environmental conditions and is the result of the rapid breakdown and mineralization of simple organic compounds [13]. The composting process consists of a mesophilic, thermophilic, cooling and curing phase. In the thermophilic phase, the temperature inside the compost matter can reach up to $80^{\circ} \mathrm{C}$ [14]. Compost with the addition of sawdust was characterized by the highest temperature $\left(56^{\circ} \mathrm{C}\right)$ within the compost mass. The parameters obtained in our experiment can be confirmed by studies conducted by Liao et al. [15], in which compost with sawdust added as a substrate for the breakdown of fish by-products reached a temperature of $55^{\circ} \mathrm{C}$ during the first week of the process. The increase in temperature was the lowest in the case of compost to which straw and lignite had been added, with the maximum value of $38^{\circ} \mathrm{C}$ reached on the 8th day of composting. Biochar can be a habitat for microorganisms due to its large surface area and microporosity [16]. After three weeks of composting, the temperature was lower and oscillated in the range of $25^{\circ} \mathrm{C}$ for the following two weeks. A decrease in temperature signifies a decreasing number of hemophilic bacteria and indicates a drop in assimilable organic substances, along with an increase in mineral compounds [17]. After seven weeks of composting, the temperature in all analysed objects fell again, becoming closer to the atmospheric air temperature, which may indicate the completion of the composting process.

The $\mathrm{pH}$ of the composting mass can be a good indicator of the state of the curing process. The mineralization of organic substances and decrease in the $\mathrm{pH}$ of the environment may be accompanied by the release of mobile forms of metals which, upon having undergone biosorption, can create organic complexes with newly created humic substances [18]. Values of $\mathrm{pH}$ between 6.7 and 9.0 ensure a proper course of microbiological processes, whereas optimal $\mathrm{pH}$ falls into the range of 5.5 to 8.0 [19]. During the analyzed composting process, $\mathrm{pH}$ values increased up until week 4 of the process, and reached maximum values of 8.2 in the compost with the addition of straw (Fig. 2). A fall in $\mathrm{pH}$ was observed in all bins after the fourth and fifth weeks of the process, with final values of 6.6-7.9.

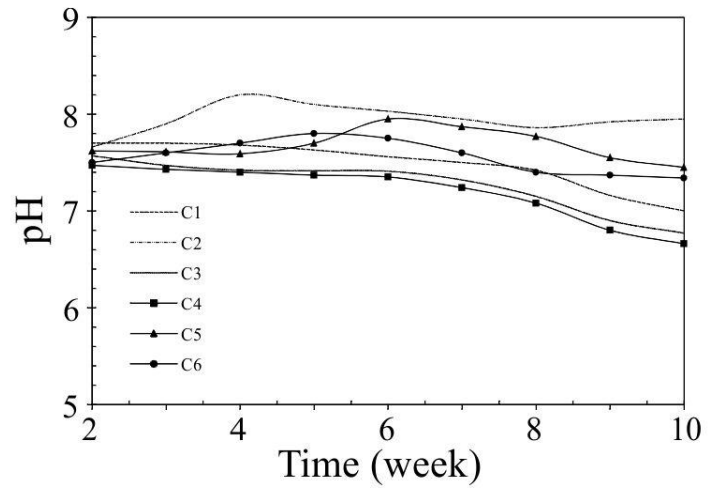

Fig. 2 Changes in $\mathrm{pH}$ during the composting process $\left({ }^{\circ} \mathrm{C}\right)$

The value of electrical conductivity (EC) is a measure of the intensity of changes taking place, as well as an indicator of the rate at which assimilable forms of mineral components are activated. A decrease in specific conductance can signify a prevalence of processes binding mineral components with the 
sorption complex, whereas an increase indicates a greater intensity of processes in which mineral forms of components are released. In all composts, a systematic increase in the value of specific conductance occurred, reaching the maximum value in the last week of the process (Fig. 3). The values of specific conductance were the highest in compost with the addition of bark and brown coal as compared to the remaining experimental variants, reaching a maximum value of 7.30 $\mathrm{mS} \mathrm{cm}{ }^{-1}$.

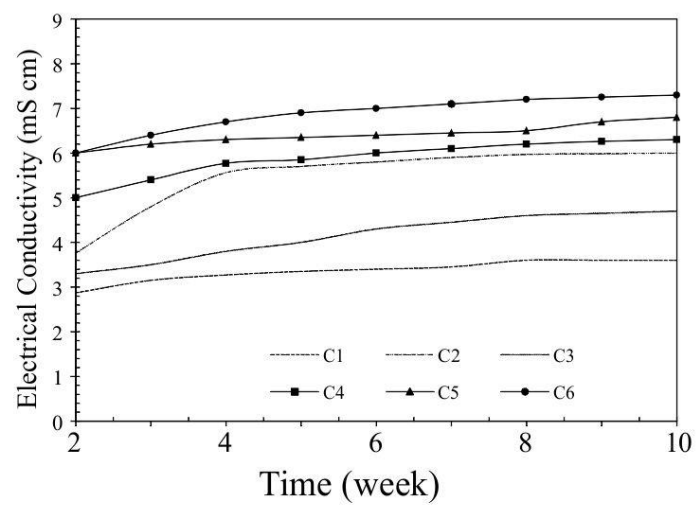

Fig. 3 Changes in electrical conductivity during the composting process $\left(\mathrm{mS}^{\circ} \mathrm{cm}^{-1}\right)$

By improving the physical, chemical, and biological properties of the soil, composts may stimulate crop yields [20]. The influence of variable organic fertilization on the crop yield of maize has been confirmed by the studies of Sieling, Christen [21], Ren et al. [22] and Millar et al. [23]. The crop yield of Brassica napus L. indicated a clear differentiation and was influenced by the type of compost $\left(\mathrm{C}_{1}-\mathrm{C}_{6}\right)$ as well as mineral fertilization (Fig. 2). In the control treatments (without and with manure fertilization), the yield of the tested plant was lower than in the treatments in pots with compost $\left(\mathrm{C}_{1}-\mathrm{C}_{6}\right)$.

The average crop yield of the above-ground parts of $B$. napus

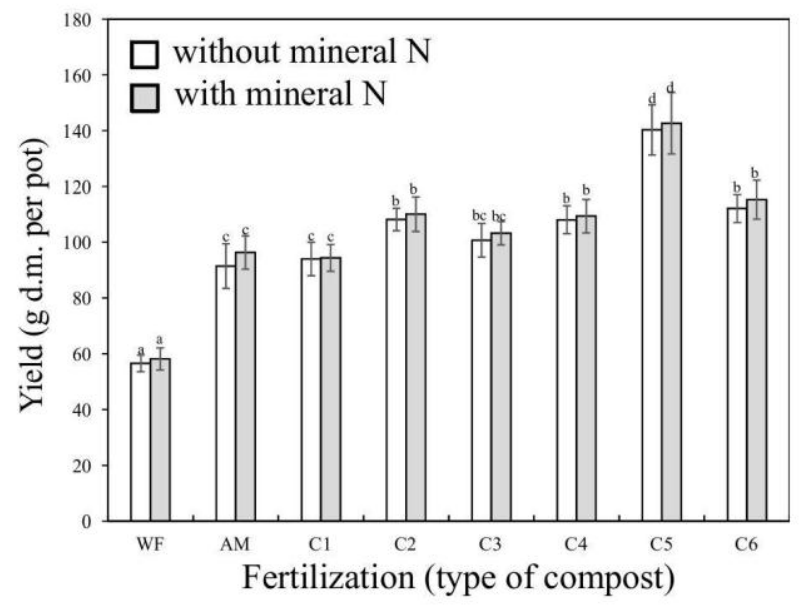

Fig. 4. Effect of fertilizer application on the yield Brassica napus L., g d.m. per pot. mean $\pm \mathrm{SD}, \mathrm{n}=3$; Columns marked with different letter indicate significant differences between members of the same set (Tukey test, $\mathrm{P}<0.05$ ).WF-without fertilization; AM-animal manure

in the series without additional mineral $\mathrm{N}$ fertilization was
$48.83 \%$ higher, and in the mineral $\mathrm{N}$ series $-48.34 \%$ higher when compared to the control objects. Authors Sikora and Enkiri [24] noted that when an $\mathrm{N}$ fertilizer was present in a blend with compost, the compost provided a higher crop yield. The highest crop yield of B. napus was noted in the case of compost containing straw with the addition of lignite. Compost with bark and lignite also produced a positive, although weaker, effect. The addition of lignite (composts $\mathrm{C}_{4}-\mathrm{C}_{6}$ ) significantly influenced the crop yield of the above-ground parts of $B$. napus as compared to composts without lignite $\left(\mathrm{C}_{1}-\mathrm{C}_{3}\right)$. This yield increase seems to be caused mainly by improved soil structure and enhanced nutritional status of the plants [25].

\section{CONCLUSIONS}

The addition of organic substrates to the compost biomass had a significant influence on the dynamics of its changes in the composting process. The obtained results indicate that the addition of straw to compost mass containing by-products of the fishing industry resulted in the highest temperature during the course of the process when compared to composts with the addition of other organic substrates. This suggests that the appropriate compost substrates were chosen, which facilitated the presence of high temperatures that are essential for the hygienization of the by-products. The $\mathrm{pH}$ parameter recorded in mature composts indicates good compost quality and the possibility of using it as fertilizer under domestic conditions. The yield of Brassica napus L. depended on mineral $\mathrm{N}$ fertilization as well as the type of compost mixtures applied to the soil. The average crop yield of the above-ground parts of B. napus $\mathrm{L}$. in the series without mineral fertilization and series with mineral $\mathrm{N}$ fertilization was higher compared to the control series. The highest crop yield of tested plant was noted in the case of applying compost containing fish by-products and straw with the addition of lignite, and with bark and lignite.

\section{REFERENCES}

[1] C. Lopes, L. T. Antelo, A. Franco-Uría, A. A. Alonso, and R. PérezMartín, "Valorisation of fish by-products against waste management treatments - Comparison of environmental impacts," Waste Manage., vol. 46, pp. 103-112, 2015.

[2] L. E. Fels, N. Hafidi, J. Silvestre, J. Kallerhoff, G. Merlina, and E. Pinelli, "Efficiency of co-composting process to remove genotoxicity from sewage sludge contaminated with hexavalent chromium," Ecol. Eng., vol. 82, pp. 355-360, 2015.

[3] Z. Usydus, H. Górecki, Z. Dobrzański, and M. Świerczewska, "Using liquid waste from fishing industry for production of biocompost," "Wykorzystanie płynnych odpadów z przemysłu rybnego do produkcji biokompostu," [in Polish], Acta Agrophis., vol. 1 (4), pp. 773-778, 2003.

[4] A. Moldes, Y. Cendón, and M. T Barral, "Evaluation of municipal solid waste compost as a plant growing media component, by applying mixture design," Bioresource Technol., vol. 98, pp. 3069-3075, 2007.

[5] A. Piotrkowska-Cyplik, Ł. Chrzanowski, P. Cyplik, J. Dach, A. Olejnik, J. Staninska, et al., "Composting of oiled bleaching earth: fatty acids degradation, phytotoxicity and mutagenicity changes," Int. Biodeterior Biodegr., vol. 78, pp. 49-57, 2013.

[6] H. Egner, H. Riehm, and W. R. Domingo, Untersuchungen über die chemische Bodenanalyse als Grundlage für die Beurteilung des 
Nährstoffzustandes der Böden. II. Chemische Extractionsmethoden zur Phospor- und Kaliumbestimmung. Annals Royal Agricultural College 26, CA: Sweden, 1960, pp. 199-215.

[7] E. Schlichting, H. P. Blume, and K. Stahr, Bodenkundliches Praktikum. Pareys Studientexte 81. Blackwell Wissenschafts-Verlag, CA: Berlin, 1995.

[8] A. Ostrowska, S. Gawliński, and Z. Szczubiałka, Methods for analysis and evaluation of soil and plant properties. Institute of Environmental Protection, CA: Warsaw, 1991.

[9] A. Klute, Methods of soil analysis. Madison: American Society of Agronomy. Agronomy, Monograph 9, 1996.

[10] A. Singh, K. Billingsley, and O. Ward, "Composting: a potentially safe process for disposal of genetically modified organisms,". Crit. Rev. Biot., vol. 26, pp. 1-16, 2006.

[11] M. T. Chan, A. Selvam, and J. W. C. Wong, "Reducing nitrogen loss and salinity during 'struvite' food waste composting by zeolite amendment," Bioresource Technol., vol. 200, pp. 838-844, 2016.

[12] Y. Wang, and P. Ai, "Integrating particle physical geometry into composting degradation kinetics," Bioresource Technol., vol. 200, pp. 514-520, 2016.

[13] R. Cáceres, N. Coromina, K. Malińska, and O. Marfà, "Evolution of process controlparameters during extended co-composting of green waste and solid fraction of cattle slurry to obtain growing media," Bioresour. Technol., vol. 179, pp. 398-406, 2015.

[14] A. Guardia, C. Petiot, and D. Rogeau, "Influence of aeration rate and biodegrability fractionation on composting kinetics," Waste Manage., vol. 28, pp. 73-84, 2006.

[15] P.H. Liao, A. C. May, S. T. Chieng, "Monitoring process efficiency of a full-scale in vessel system for composting fisheries wastes, "Bioresour. Technol., vol. 54, pp. 159-163, 1995.

[16] L. Wei, W. Shuato, Z. Jin, and X. Tong, "Biochar influences the microbial community structure during tomato stalk composting with chicken manure," Bioresour. Technol., vol. 154, 148-154, 2014.

[17] T. Gea, A. Artola, and A. Sanchez, "Composting of de-inking sludge from the recycled paper manufacturing industry," Bioresour. Technol. vol. 96, pp. 1161-1167, 2005.

[18] S. Amir, M. Hafidi, G. Merlina, and J. C. Revel, "Sequential extraction of heavy metals during composting of sewage sludge," Chemosphere, vol. 59, no. 6, pp. 801- 810, 2005.

[19] F.C. Miller, "Composting as a process based on the control of ecologically selective factors," in F. B. Jr. Metting (Ed.), Soil Microbial Ecology, Applications in Agricultural and Environmental Management. Marcel Dekker Inc., CA: New York, 1992, pp. 515-544.

[20] M. Wyszkowski, and M. Radziemska, "Effects of chromium (III and VI) on spring barley and maize biomass yield and content of nitrogen compounds," J. Toxicol. Environ. Health, A, vol. 73, no. 17, pp. 1274 $1282,2010$.

[21] K. Sieling, and O. Christen, "Crop rotation effects on yield of oilseed rape, wheat and barley and residual effects on the subsequent wheat," Arch. Agron. Soil Sci., vol. 61, no. 11, pp. 1531-1549, 2015.

[22] T. Ren, H. Li, J. Lu, R. Bu, X. Li, R. Cong, and M. Lu, "Crop rotationdependent yield responses to fertilization in winter oilseed rape (Brassica napus L.),". Crop J., vol. 3, pp. 396-404, 2015.

[23] J. L. Millar, D. K. Michael, B. A. Chan, A. Dufresne, M. Summer, and M. F. Belmonte, "Chalazal seed coat development in Brassica napus,". Plant Sci., vol. 241, pp. 45-54, 2015.

[24] L. J. Sikora, and N. K. Enkiri, "Efficiency of compost-fertilizer blends compared with fertilizer alone". Soil Sci., vol. 165, pp. 444-451, 2000.

[25] Z. Mazur, M. Radziemska, "Influence of compost from fish by-products on nutrient supply in radish," Ecol Chem Eng A. vol. 21, no. 2, pp. 231240,2014 